\section{A NOTE ON FIVE FRESHWATER SPONGES (PORIFERA: SPONGILLINA: SPONGILLIDAE) FROM PUNE, MAHARASHTRA, INDIA}

\author{
Shriraj S. Jakhalekar ${ }^{1} \&$ H. V. Ghate ${ }^{2}$ \\ 1,2 Post-Graduate Research Centre, Department of Zoology, Modern College of Arts, Science \& Commerce, Shivajinagar, \\ Pune, Maharashtra 411005, India \\ ${ }^{1}$ shriraj.jak@gmail.com, ${ }^{2}$ hemantghate@gmail.com (corresponding author)
}

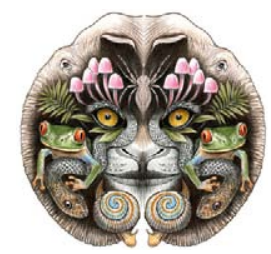

ISSN

Online 0974-7907

Print 0974-7893

OPEN ACCESS
Abstract: We report the presence of five freshwater sponges in ephemeral and permanent fresh water bodies in and around Pune, Maharashtra, India. Field observations, descriptive notes, habitus photographs and SEM photographs of body spicules, gemmule spicules and gemmules of five species are provided. Eunapius carteri (Bowerbank, 1863), Radiospongilla cerebellata (Bowerbank, 1863) and Corvospongilla lapidosa (Annandale, 1908) are commonly occurring species, whereas Ephydatia meyeni (Carter, 1849) and Dosilia plumosa (Carter, 1849) are rarely found. This report fills a longstanding gap in observations of freshwater sponges near Pune, and it is heartening to note that species reported earlier are still found in these environs.

Keywords: Corvospongilla lapidosa, descriptive notes, Dosilia plumosa Eunapius carteri, Ephydatia meyeni, Pune, Radiospongilla cerebellata, SEM, Spongillidae.

Phylum Porifera, members of which are commonly known as sponges, consists of over 8500 species distributed worldwide, mostly in marine environments. Sponges are aquatic, sessile filter-feeding invertebrates that may also utilize dissolved organic matter from water, and some may be carnivorous. Over $83 \%$ of species belong to Class Demospongiae, of which the vast majority are marine although there are many species of freshwater sponges (see van Soest et al. 2012, for a detailed overview). All freshwater sponges are now grouped under suborder Spongillina (Manconi \& Pronzato 2002) of the order Haplosclerida, and this suborder includes 44 genera classified under six families of extant sponges, of which the Oriental Region possesses 11 genera and 37 species belonging to two families, namely Spongillidae and Metaniidae (Manconi \& Pronzato 2008). The suborder Spongillina has been defined by Manconi \& Pronzato (2002) as containing exclusively freshwater sponges that possess megascleres-oxeas or strongyles - that are smooth or spined, forming paucito multi-spicular tracts producing, irregular to regular meshes, occasionally with large alveolate cavities; where spongin material is mostly sparse; microscleres present or absent, including smooth or spined oxeas, aster-like or birotule like spicules. Only four families produce gemmules or resting bodies that contain totipotent cells enclosed in protective cover. These gemmules, which allow the sponges to survive desiccation, often contain special spicules or gemmuloscleres of diverse morphology that are used in identification of species (see Manconi \& Pronzato 2002, for a detailed review and keys to the families / genera of freshwater sponges). Both body and gemmule spicules as well as gemmule

\footnotetext{
DOI: http://dx.doi.org/10.11609/JoTT.o3356.4392-403| ZooBank: urn:Isid:zoobank.org:pub:1C5DEFC7-41F8-49FC-B6A5-6DDD2760E4A4

Citation: Jakhalekar, S.S. \& H.V. Ghate (2013). A note on five freshwater sponges (Porifera: Spongillina: Spongillidae) from Pune, Maharashtra, India. Journal of Threatened Taxa 5(9): 4392-4403; http://dx.doi.org/10.11609/JoTT.03356.4392-403
}

Copyright: (c) Jakhalekar \& Ghate 2013. Creative Commons Attribution 3.0 Unported License. JoTT allows unrestricted use of this article in any medium, reproduction and distribution by providing adequate credit to the authors and the source of publication.

Funding: Self funded.

Competing Interest: None.

Acknowledgements: The authors express their deepest gratitude to Dr. Klaus Ruetzler (USA) and Dr. Alexander Ereskovsky (France) for providing valuable literature and reviewing the first draft of the manuscript. Dr. R. Sharma (Officer-In-Charge, ZSI, Pune) permitted access to the library at the Zoological Survey of India, Pune; Mr. Jadhav and Ms. S. Paripatyadar extended their help during the referencing work. Sincere thanks to them. SSJ is particularly thankful to his lab-mates, Girish, Sameer, Yugandhar, Swapnil and Mihir, for their help in the field and during sample preparation for SEM and photography. We thank the Department of Physics, University of Pune, for use of the SEM facility and Mr. Shinde for technical assistance. The authors are also grateful to the authorities of the Modern College for facilities and encouragement. 
morphology are thus important structures and need attention. Considerable work on sponges is being done around the world and there is an online World Porifera Database at: www.marinespecies.org/porifera/ (van Soest et al. 2013). In a recent paper on global diversity of freshwater sponges Manconi \& Pronzato (2008) mention that the total number of species is 219 , and of these 103 (i.e., 47\%) are endemic.

All over the world there is an increasing interest in study of sponges, or 'Spongology,' which has been defined as the study of all aspects of their biology, ecology and taxonomy. As mentioned by van Soest et al. (2012), apart from academic interest sponges can produce chemical compounds with pharmaceutical properties, including some with anti-tumor, anti-infective and antiinflammatory properties. There is thus a need to study our sponge fauna.

After the pioneering work on diversity and biology of the sponges of the Indian subcontinent by Annandale (1911), no significant addition or contribution has been made by later workers; especially with respect to the knowledge of systematics and biology of Indian freshwater sponges. Annandale listed 23 species of freshwater sponges under seven genera (including subspecies) in the main text and added two more as an addenda, and gave detailed notes about their distribution and biology in his classic 'Freshwater Sponges, Hydroids \& Polyzoa' in 'The Fauna of British India' volume. Penney \& Racek (1968), in their 'Comprehensive Revision of a Worldwide Collection of Freshwater Sponges', added substantial information; they also revised taxonomy of the group. Annandale's Fauna published in 1911, however, includes species outside the present Indian territory. In the present Indian prospect 30 species of freshwater sponges belonging to 10 genera, represented by a single family Spongillidae Gray, 1867, are known to be present (Soota 1991). This is a significant number in that over $81 \%$ ( 30 species out of 37 known) of the Oriental species are found in India.

Attempts to summarize knowledge of Indian freshwater sponges following Annandale (1911) include publications by Khera \& Chaturvedi (1976) and Soota (1991). A few reports and checklists concerning freshwater sponges from different regions of India have also been published (Tonapi 1964; Rao \& Khan 1982; Soota \& Pattanayak 1982; Patil 1986; Dutta et al. 2000; Devarshi 2006; Patil \& Talmale 2007; Kakavipure \& Yeragi 2008), however, detailed work on the biology or systematics of Indian freshwater sponges using modern techniques like scanning electron microscopy (SEM) imaging and DNA barcoding has not been attempted.
In this paper we provide views of internal morphology of gemmules using SEM because gemmule structure is considered diagnostic. We feel there is a need for fresh surveys and collection since freshwater habitats are rapidly undergoing drastic modification.

\section{Materials and Methods}

Sponges were collected from two freshwater habitats from Pune City. (i) A temporary freshwater pool near Dighi, Alandi Road, Pune (Image 1). This water body is about $50 \mathrm{~m}$ in diameter. The maximum known depth is about 6-8 $\mathrm{m}$. There are few submerged and emergent aquatic plants and much of the bottom is rocky. There is no major water-body in the vicinity; (ii) A man-made permanent freshwater habitat, Pashan Tank, Pune (Images 2\&3). This tank is about $500 \mathrm{~m}$ in diameter. The maximum known depth is about $12-15 \mathrm{~m}$. Aquatic plants are present in good numbers and the invertebrate fauna is also rich (H.V. Ghate unpublished). It is one of the favourite destinations for birds migrating in winter. Anthropogenic activities, like swimming, fishing are a regular practice. Pashan tank was constructed as a permanent freshwater reservoir to supply potable water.

Sponges were visually located in the peripheral shallow margins of the water-bodies. Surveys were also conducted in dry seasons so as to collect the dry sponges (with large number of gemmules), exposed due to receded water levels. Sponges were photographed in field with a digital camera (Canon PowerShot A2100 IS) and then scraped off from the substrata using a scalpel. Dried sponges were kept without any chemical treatment; small pieces of live sponges were either fixed and preserved in $70 \%$ ethanol or simply dried.

For light microscopic observations, permanent preparations were made of body as well as gemmulespicules for all species by boiling small pieces of sponge in concentrated $\mathrm{HNO}_{3}$, dehydrating through pure ethanol and finally mounting in synthetic medium Distyrene Plasticizer Xylene (DPX, Qualigen).

Forscanning electron microscopic(SEM) investigation, spicules isolated with above method were thoroughly washed with absolute ethanol and dried. Gemmules from dry preserved sponges were soaked in $70 \%$ ethanol overnight, in order to avoid the preservation artefacts in morphology. A clean cut, passing right through the foramen and foraminal tube of the gemmule, was made using a sharp blade. Both intact as well as cut gemmules were treated with absolute ethanol and then treated with hexamethyldisilazane (HMDS, SRL Chemicals), and 


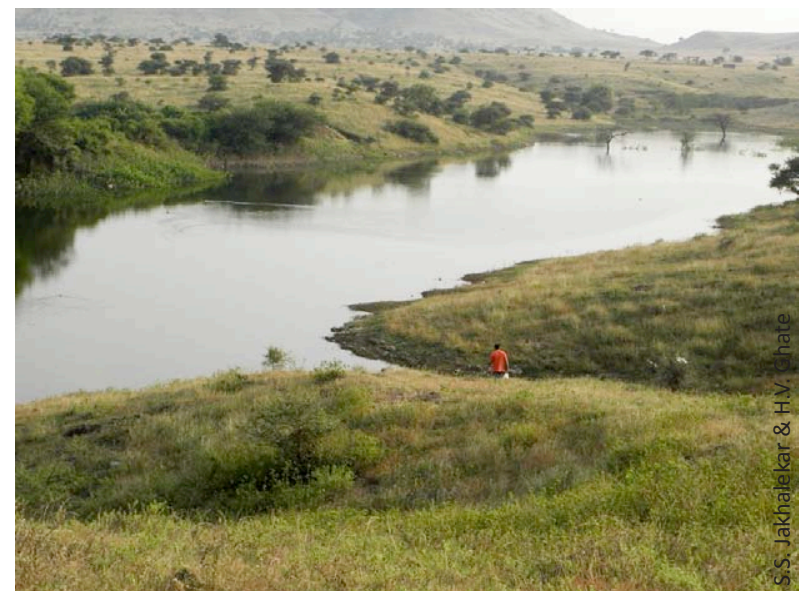

Image 1. Ephemeral pool at Dighi, Pune.

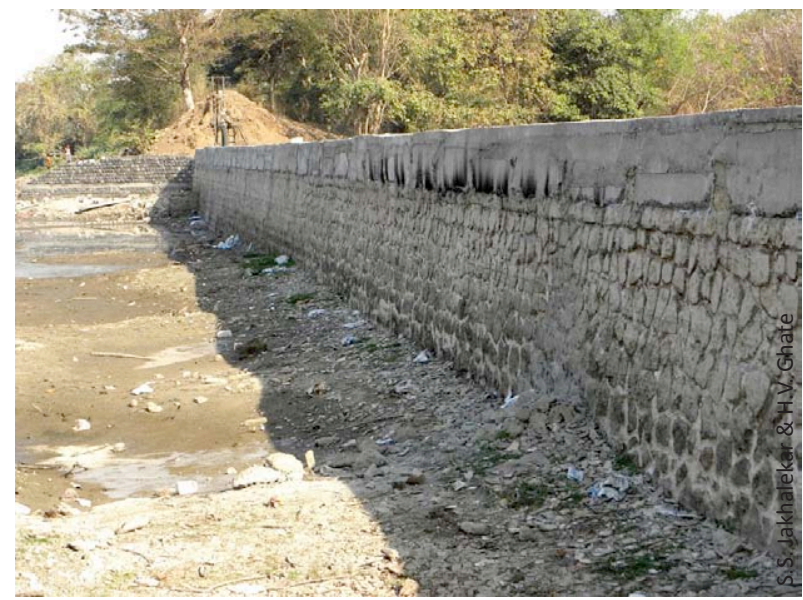

Image 3. Rocky bund-wall of Pashan reservoir, Pune.

allowed to dry, as per the protocol given by Nation (1983). Processed spicules and gemmules were mounted on the SEM stub with the help of double sided carbon-tape. Samples were sputter-coated with platinum (at thickness of about 15nm) and scanned and photographed using Analytical SEM (JEOL JSM - $6360 \mathrm{~A}$ ) with voltage at 10kV and 20kV for spicules and gemmules, respectively. Digital SEM images were cleaned and adjusted for contrast using Adobe Photoshop CS5 Version 12.0.

Determination of species was based on careful microscopic examinations of these permanent preparations and with the help of keys and diagrams given by Annandale (1911) alone while their recent nomenclatural status was checked with Penney \& Racek (1968). No other original papers on sponge taxonomy were consulted to identify a species. References for the authority of various genera and species as well as synonyms, which are usually cited only in taxonomic large treatises, and are cited by Annandale (1911) and

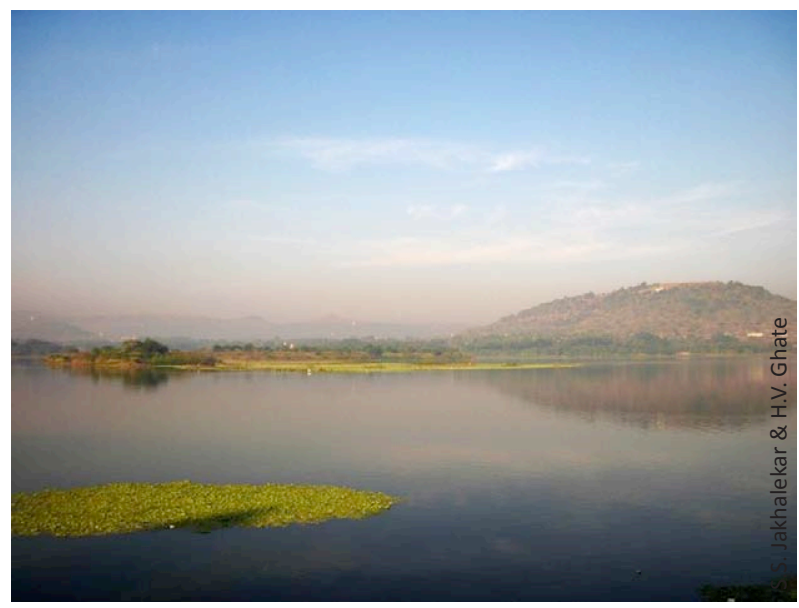

Image 2. Manmade permanent water reservoir at Pashan, Pune.

Penney \& Racek (1968), are therefore not cited again in this communication. Readers are therefore referred to these original works for additional information. Morphometry of various kinds of spicules and gemmules was performed by using stage and ocular micrometer and by analysing the SEM images with Adobe Photoshop. For measurement, 10 gemmules and spicules of each type were analyzed under light microscope. As far as possible, while describing our material we have used the standard terminology provided by Boury-Esnault \& Ruetzler (1997).

\section{Observations and Comments}

We provide additional information about five species offreshwatersponges, viz., Dosilia plumosa (Carter, 1849); Radiospongilla cerebellata (Bowerbank, 1863); Ephydatia meyeni (Carter, 1849); Eunapius carteri (Bowerbank, 1863) and Corvospongilla lapidosa (Annandale, 1908), all belonging to Spongillina: Spongillidae, collected from Pune. We provide habitus photographs and SEM images of body as well as gemmule-spicules and gemmules for all species for the first time in the sense that no Indian work has given this information before, although a few species have been investigated by foreign workers using SEM. For each species we are giving brief comments on habitus and also diagnostic characters with respect to spicules and gemmules.

\section{Dosilia plumosa (Carter, 1849)}

Genus Dosilia Gray, 1867 (type species: Spongilla plumosa Carter, 1849), according to a recent revision by Cândido et al. (2010), includes five species and D. plumosa is the only member known from Indian freshwaters (Annandale 1911; Penney \& Racek 1968; 
Soota 1991; Manconi \& Pronzato 2002; Cândido et al. 2010).

Dosilia plumosa were collected in November 1998 from a temporary freshwater pool located near Dighi, Alandi road, Pune (collector H.V. Ghate) (Image 1).

Habitus: The sponge was found attached to submerged plants as well as rocks in shallow regions of the pond (maximum depth about $30 \mathrm{~cm}$ ). Live sponge is often bright green in colour and exhibits typically lobed and irregular body shape; oscula are small. Body is moderate in size, soft and often very fragile.

\section{Diagnostic characters}

Spicules (Images 4A-C): Megascleres are feebly curved, slender, entirely smooth oxeas (311-541 x 14-18 $\mu \mathrm{m}$ ) (Image 4A). Microscleres are euasters chiefly nodular at centre with $10-12$ rays radiating in all directions; rays generally with smooth shaft but bearing minute recurved spines in terminal regions (diameter: 25-39 $\mu \mathrm{m}$ ) (Image 4B). Another kind of microslere, though sparsely present, is microspined oxeas with 2-4 rays projecting from the central region (39-68 x 18-29 $\mu \mathrm{m})$ (Image 4C). Gemmuloscleres are typically birotulate with straight, slender and entirely spined shaft with distinctly umbonate rotules having dentate margins; rotules on both ends of the shaft are almost identical in morphology (75-93 x 3-4 $\mu \mathrm{m}$; diameter of rotules: 18-25 $\mu \mathrm{m}$ ) (Image 4B\&C).

Gemmules (Images 4D-G): Gemmules were profusely found throughout the skeletal meshwork of the dried sponge. They are somewhat ovoid in shape (diameter: $700-850 \mu \mathrm{m}$ ) and a little depression is seen in dried specimen. Pneumatic layer is well developed and granular. Shafts of the gemmuloscleres are embedded perpendicularly in the pneumatic layer, whereas the rotules are left exposed on either sides of it (Images 4E\&F). Foraminal tube is distinctly seen, straight but short (Images 4E\&G).

\section{Radiospongilla cerebellata (Bowerbank, 1863)}

Genus Radiospongilla Penney \& Racek, 1968 (type species: Spongilla sceptroides Haswell, 1882), is one of the large genera of Spongillidae. Manconi \& Pronzato (2002) have summarised 15 species under this genus Osborn et al. (2008) have described a new species, Radiospongilla pedderensis from Pedder Lake, Tasmania. Six species have been reported from India: $R$. cantonensis (Gee, 1929); R. cinerea (Carter, 1849); R. crateriformis (Potts, 1882); R. hemephydatia (Annandale, 1909); $R$. indica (Annandale, 1907); and R. cerebellata (Annandale 1911; Penney \& Racek 1968; Soota 1991; Manconi \&
Pronzato 2002).

Radiospongilla cerebellata were found in December 2011 in the same ephemeral freshwater pool near Dighi, Alandi Road, Pune (collector S.S. Jakhalekar) (Image 1). Spicules and gemmules from this species matched with those of Spongilla reticulata as described by Annandale (1907); subsequently treated as Spongilla lacustris reticulata by Annandale (1911). This species is now treated as synonym of $R$. cerebellata (Bowerbank), as per Penney \& Racek (1968).

Habitus (Images 5\&6): Radiospongilla cerebellata were found attached to submerged vegetation and rocks (Image 5). Sponge often forming thin, flat cushion-like structures on surfaces of rocks; sometimes moderately large individuals (diameter: 8-10 cm) with distinct surface studded with finger-like projections. Surface shows body spicules radiating out perpendicularly and the oscula are conspicuous (Image 6). Colour in living state varies between off-white to green. Overall consistency of the sponge is loose and fragile.

\section{Diagnostic characters}

Spicules (Images 7A\&B): Megascleres are moderately stout, straight or feebly curved entirely smooth oxeas (344-410 x 11-14 $\mu \mathrm{m}$ ) (Image 7A). Microscleres are absent. Gemmuloscleres are rarely straight otherwise usually curved strongyles, covered with many small spines, the spines in the middle are erect and often subdivided whereas those on the extreme ends curve back towards the middle region (71-89 x 3-4 $\mu \mathrm{m}$ ) (Image 7B).

Gemmules (Image 7C-E): Numerous gemmules were found throughout the skeleton of dried sponge. These are also formed in projecting finger-like processes, thereby increasing the chances of dispersal in space, as the projections are more likely to break apart and carried away with wind or water currents. Gemmules are spherical in shape (diameter: 500-625 $\mu \mathrm{m}$ ) (Images 7D\&E). These possess a relatively thick pneumatic layer with minute air-spaces in the periphery. Gemmuloscleres are inserted in this layer in two distinct layers (Image 7E). The inner layer is formed by radially arranged gemmuloscleres, which are not exposed to outside. The outer layer, lying just above the inner one, is composed of horizontally or tangentially arranged gemmuloscleres with one of the ends inserted in the pneumatic layer and the other one projecting outside. The foramen is drawn into a slender, straight and comparatively longer foraminal tube which travels its way throughout the extraordinarily thick pneumatic layer (Images 7C\&E). 

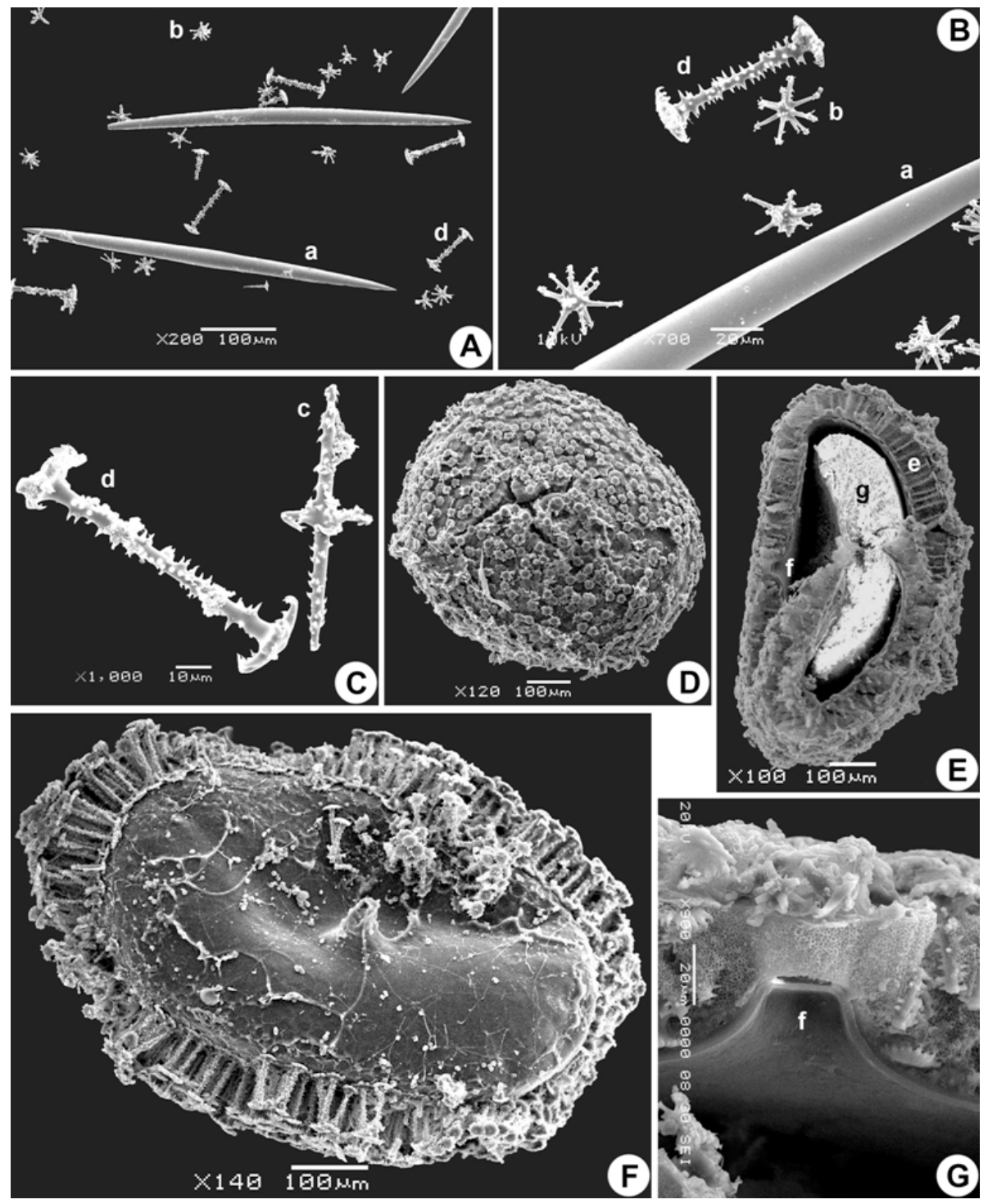

Image 4. Dosilia plumosa spicules and gemmules. A-C - megascleres, microscleres and gemmuloscleres; D - gemmule; E - cross-section of gemmule; $F$ - gemmule with the pneumatic layer peeled off showing radial arrangement of gemmuloscleres; $G$ - foraminal tube;

a - megascleres, smooth oxeas; b - microscleres, multi-rayed euasters; c - microscleres, spined oxeas with 2-3 strong spines in the centre;

d - gemmulosclere, spined birotulate; e - pneumatic layer; f - foramen \& foraminal tube; $g$ - mass of thesocytes.

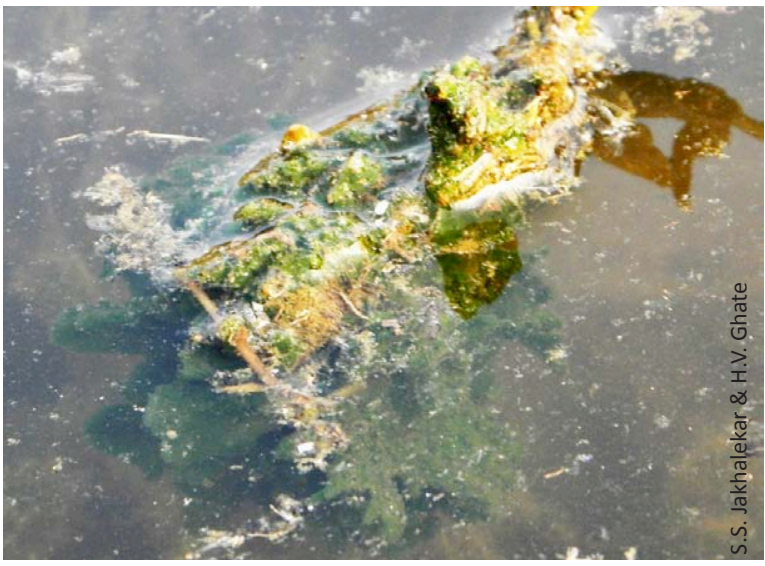

Image 5. Radiospongilla cerebellata attached to a submerged plant stem.

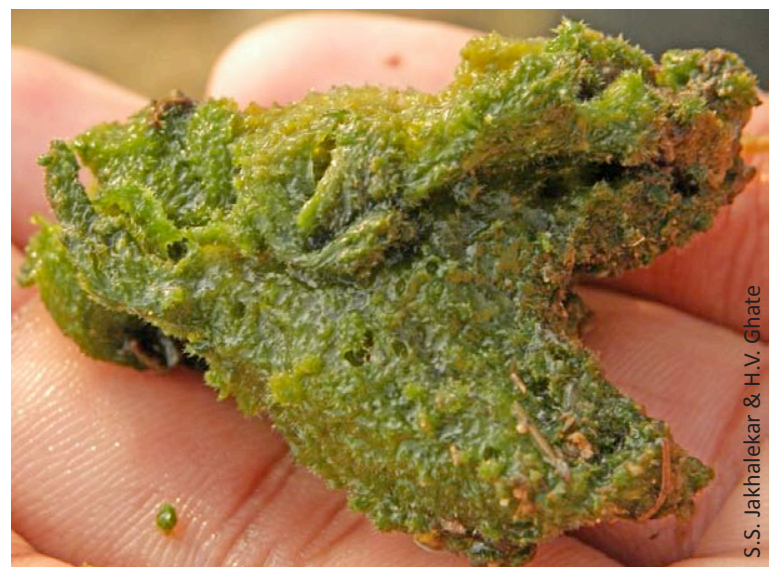

Image 6. Radiospongilla cerebellata habitus. 


\section{Ephydatia meyeni (Carter, 1849)}

Genus Ephydatia Lamouroux, 1816 (type species: Spongia fluviatilis Linnaeus, 1759), consists of nine species (Manconi \& Pronzato 2002). Only two species are known from India: $E$. fluviatilis inhabits northeastern India, whereas E. meyeni is found throughout India (Annandale 1911; Penney \& Racek 1968; Soota 1991; Manconi \& Pronzato 2002).

Ephydatia meyeni were collected in June 1997 from a man-made freshwater reservoir located at Pashan, Pune (collector H.V. Ghate) (Images 2\&3).

Habitus (Images 8\&9): Ephydatia meyeni was observed to be attached to rocky substrata. It formed drab yellowish-brown growths on the submerged surfaces of rocks. Annandale (1911) describes the sponge as flat encrustations having very little thickness. However, we observed considerably thick and globular shapes of the sponge (Image 8). We do not know the precise reason behind this, but the environmental conditions might have some role to play here. We have also collected a green specimen of $E$. meyeni from another habitat near Satara, Maharashtra in May 2012 (Image 9). Body has inconspicuous oscula, firm consistency and is moderately hard.

\section{Diagnostic characters}

Spicules (Images 10A\&B): Megascleres are moderately stout, sharply pointed, entirely smooth oxeas (344-459 x 14-21 $\mu \mathrm{m}$ ) (Image 10A). Microscleres are absent. Gemmuloscleres are birotulate, with a stout shaft and pair of identical discs, shaft is rarely smooth or usually with 1-3 erect, pointed spines which are perpendicular to the main axis; rotules are discoidal with irregular and deeply notched margins; discs are often found singly
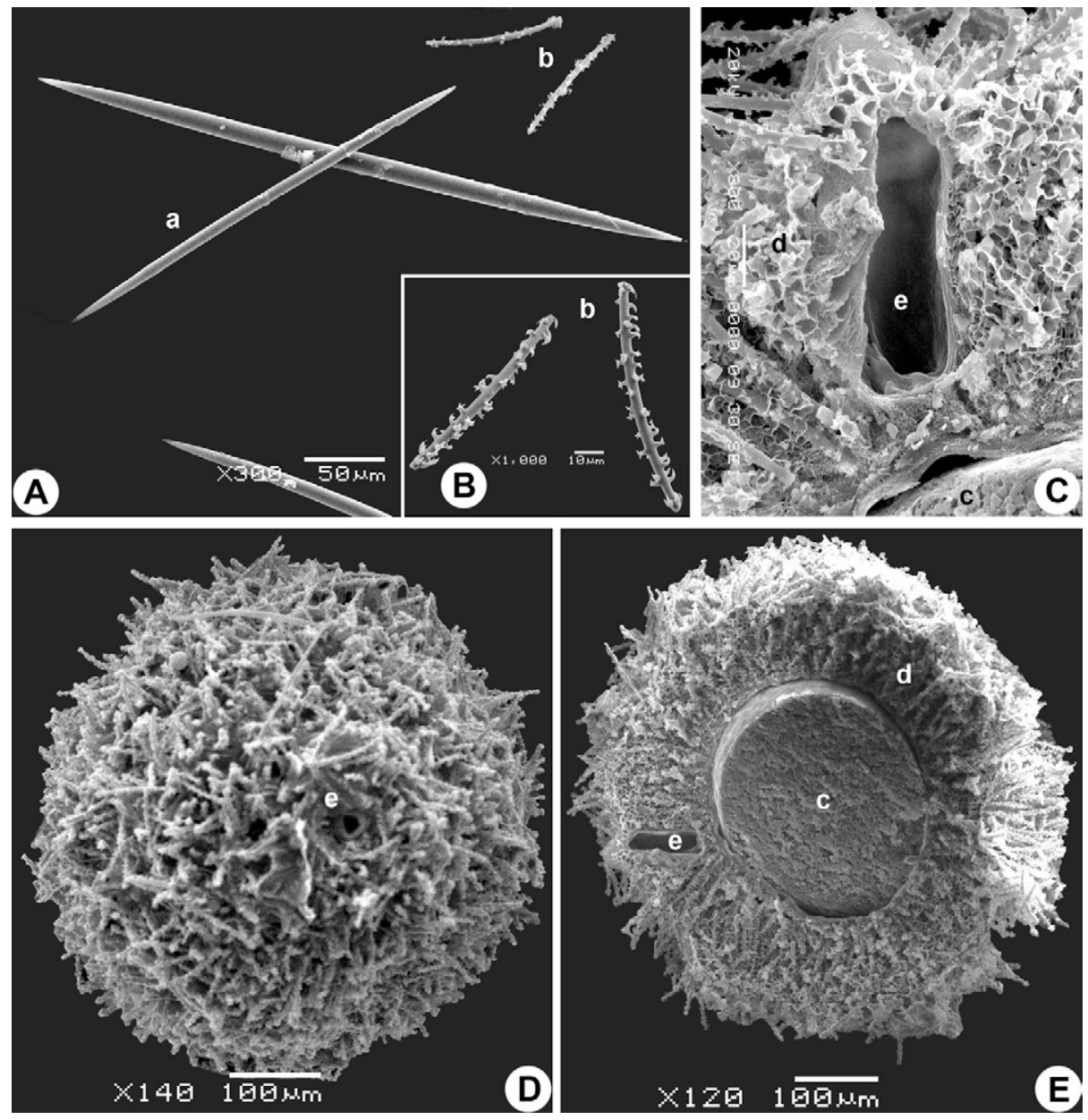

Image 7. Radiospongilla cerebellata spicules and gemmules. A - megascleres and gemmuloscleres; B - gemmuloscleres; C - pneumatic layer and foraminal tube; D - gemmule; $\mathrm{E}$ - cross-section of gemmule; $\mathrm{a}$ - megasclere, smooth oxeas; $\mathrm{b}$ - gemmulosclere, strongyles with erect subdivided spines in the middle and back-curved spines near the tip; $c$ - mass of thesocytes; $d$ - pneumatic layer showing arrangement of gemmuloscleres in two layers; e - foramen and foraminal tube. 
(25-39 x 4-7 $\mu \mathrm{m}$; diameter of rotules/discs: 18-25 $\mu \mathrm{m})$ (Images 10A\&B).

Gemmules (Images 10C-E): Gemmules were abundant in the sponge collected in summer. These were spread throughout the skeleton and were also seen on the surface (Images 8\&9). Gemmules are roughly spherical or sub-spherical (diameter: 325-375 $\mu \mathrm{m})$ (Images 10D\&E). Pneumatic layer is moderately thick, granular with irregular, small air-spaces, with gemmuloscleres embedded within it (Image 10E). Foraminal tube is not clearly visible; rather the foramen is raised slightly above the surface giving it an inverted funnel like appearance (Image 10C).

\section{Eunapius carteri (Bowerbank, 1863)}

Genus Eunapius Gray, 1867 (type species: Spongilla carteri Bowerbank, 1863), is a relatively speciose genus with 14 known species (Manconi \& Pronzato 2002). E.

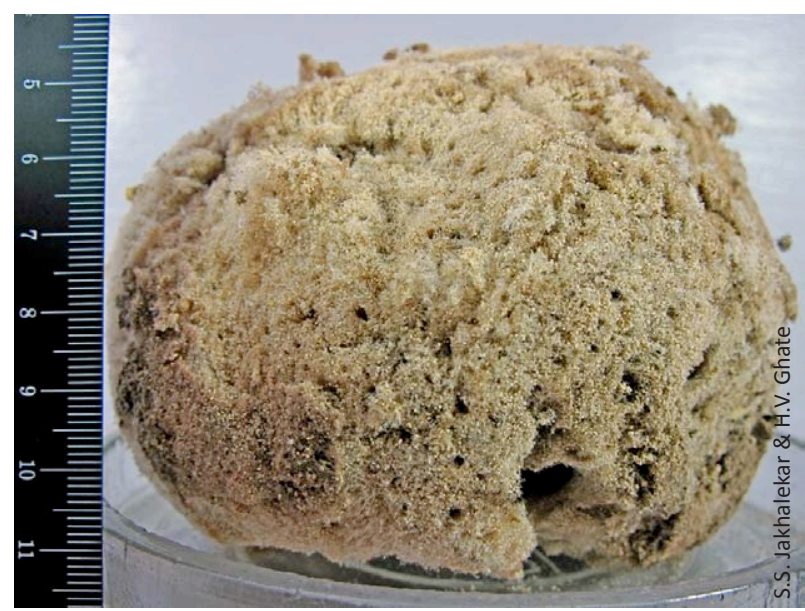

Image 8. Ephydatia meyeni habitus, dry.

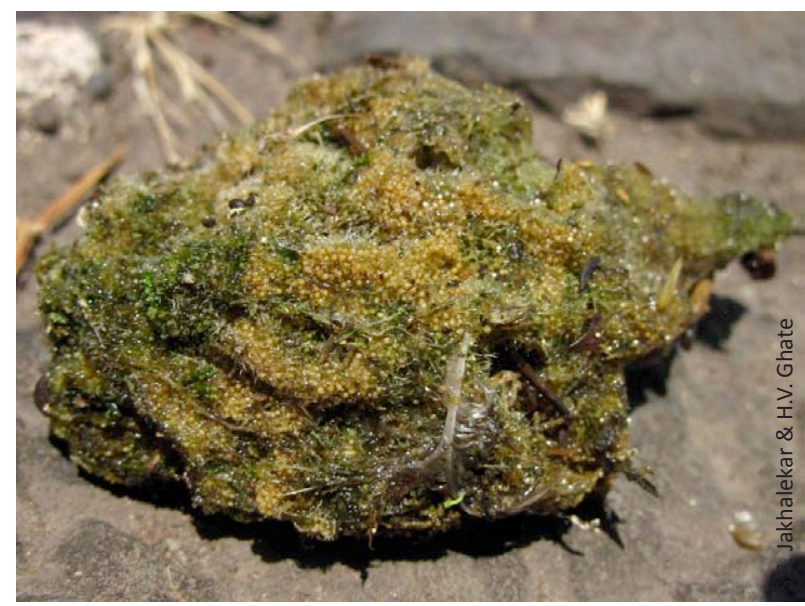

Image 9. Ephydatia meyeni habitus, live. carteri is the most widespread species in Indian region; the other Indian species are E. calcuttanus (Annandale, 1911); E. crassissimus (Annandale, 1907) and E. geminus (Annandale, 1911) (Annandale 1911; Penney \& Racek 1968; Soota 1991; Manconi \& Pronzato 2002).

Eunapius carteri were also collected from Pashan Tank, Pune in February 2012 (collector S.S. Jakhalekar) (Images 2\&3).

Habitus (Images 11\&12): Numerous individuals of Eunapius carteri were found attached to the rocky wall of Pashan Tank (Image 3). This sponge grows huge in size and these also outnumber any other sponge sharing the habitat. The sponges were roughly circular in shape and measured up to $20 \mathrm{~cm}$ across (Image 11). Dried specimens are pale to dark yellow (Image 11), whereas colour of live animal ranges from yellow to green (Image 12). Surface, in life, is mostly irregular, thrown into stubby projections with broad base and often interrupted by large oscula measuring 3-4 $\mathrm{mm}$ in diameter. Oscula are not raised above the surface (Image 12). Numerous tubificid worms and chironomid larvae were found living in association with the live sponge. Dead sponge, having lost its consistency and left only with its skeleton, offers shelter to small insects like bugs.

\section{Diagnostic characters}

Spicules (Image 13A): Megascleres are quite stout, straight or feebly curved entirely smooth oxeas (318-364 $x$ 14-18 $\mu \mathrm{m})$. Microscleres are absent. Gemmuloscleres resemble megascleres but are much smaller in size, slender and as a rule slightly curved and smooth oxeas (114-179 x 4-7 $\mu \mathrm{m}$ ) (Image 13A).

Gemmules (Image 13B-D): Abundant and were scattered singly throughout the skeleton of the sponge. These were unevenly distributed; densely towards the substratum and sparsely elsewhere. These are subspherical and are found in a variety of sizes (diameter: 525-600 $\mu \mathrm{m})$. Gemmuloscleres are horizontally or tangentially arranged on the periphery of the thick multilayered pneumatic layer (Images 13C\&D). Penney \& Racek (1968) describe the foramen to be surrounded by a crater like depression. We did not observe any depression in our fresh material, so it could simply be due to artefacts occurring during preservation. Annandale (1911) finds apt resemblance between the shapes of the foraminal tube and an inverted bottle (Images 13B\&D).

\section{Corvospongilla lapidosa (Annandale, 1908)}

Genus Corvospongilla Annandale, 1911 (type species: Spongilla loricata Weltner, 1895) was recently revised by Manconi \& Pronzato (2004). While describing a new 


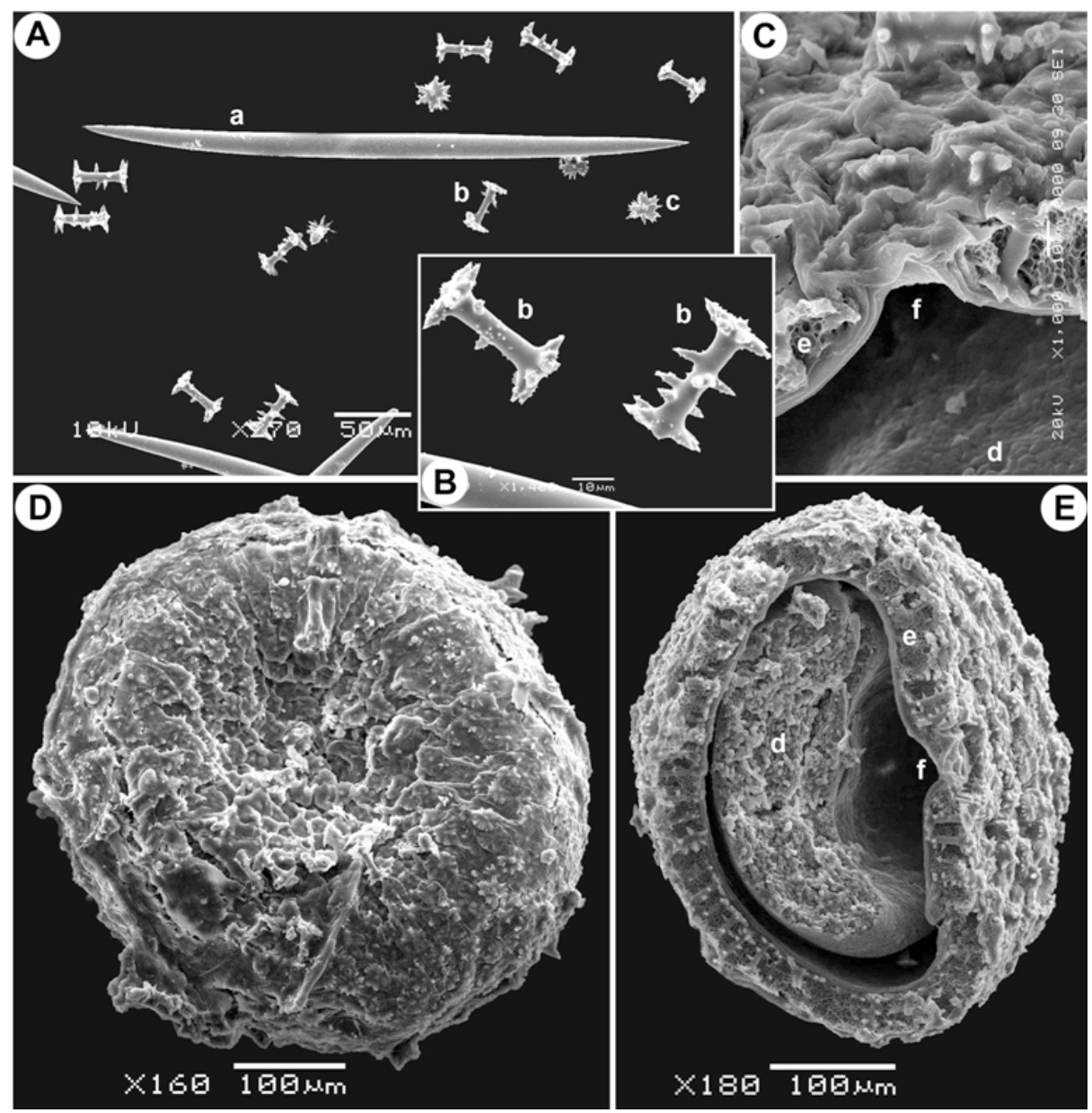

Image 10. Ephydatia meyeni spicules and gemmules. A - megascleres and gemmuloscleres; B - gemmuloscleres; C - pneumatic layer and foramen; D - gemmule; E - cross-section of gemmule; a - megasclere, smooth oxeas; b - gemmulosclere, birotulates with discoidal rotules and spiny stout shaft; $\mathrm{c}$ - discs, probably detached from the birotulates; $d$ - mass of thesocytes; $\mathrm{e}$ - pneumatic layer; $\mathrm{f}$ - elevated foramen.

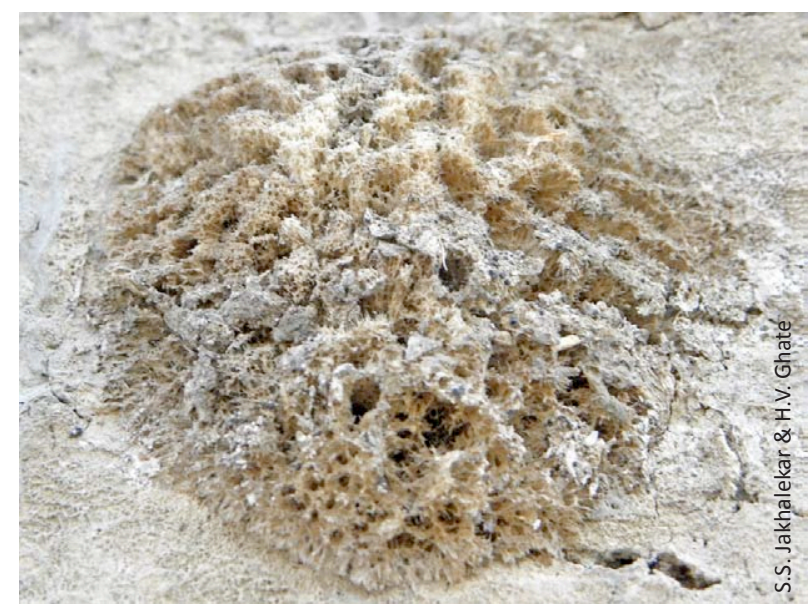

Image 11. Eunapius carteri habitus, dry skeleton.

species of Corvospongilla from Thailand, Ruengsawang et al. (2012) have stated that the current number of species under this genus is 19. Five species viz. C. burmanica

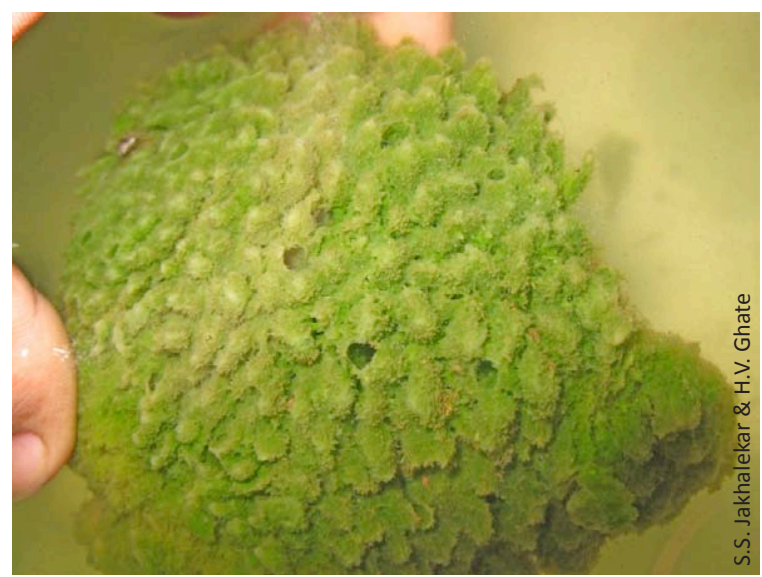

Image 12. Eunapius carteri habitus, active sponge with irregular surface thrown into stubby projections and large oscula.

(Kirkpatrick, 1908); C. caunteri Annandale, 1911; C. ultima Annandale, 1910; C. bhavnagarensis Soota et al., 1983 and C. lapidosa are known to be present in India. 

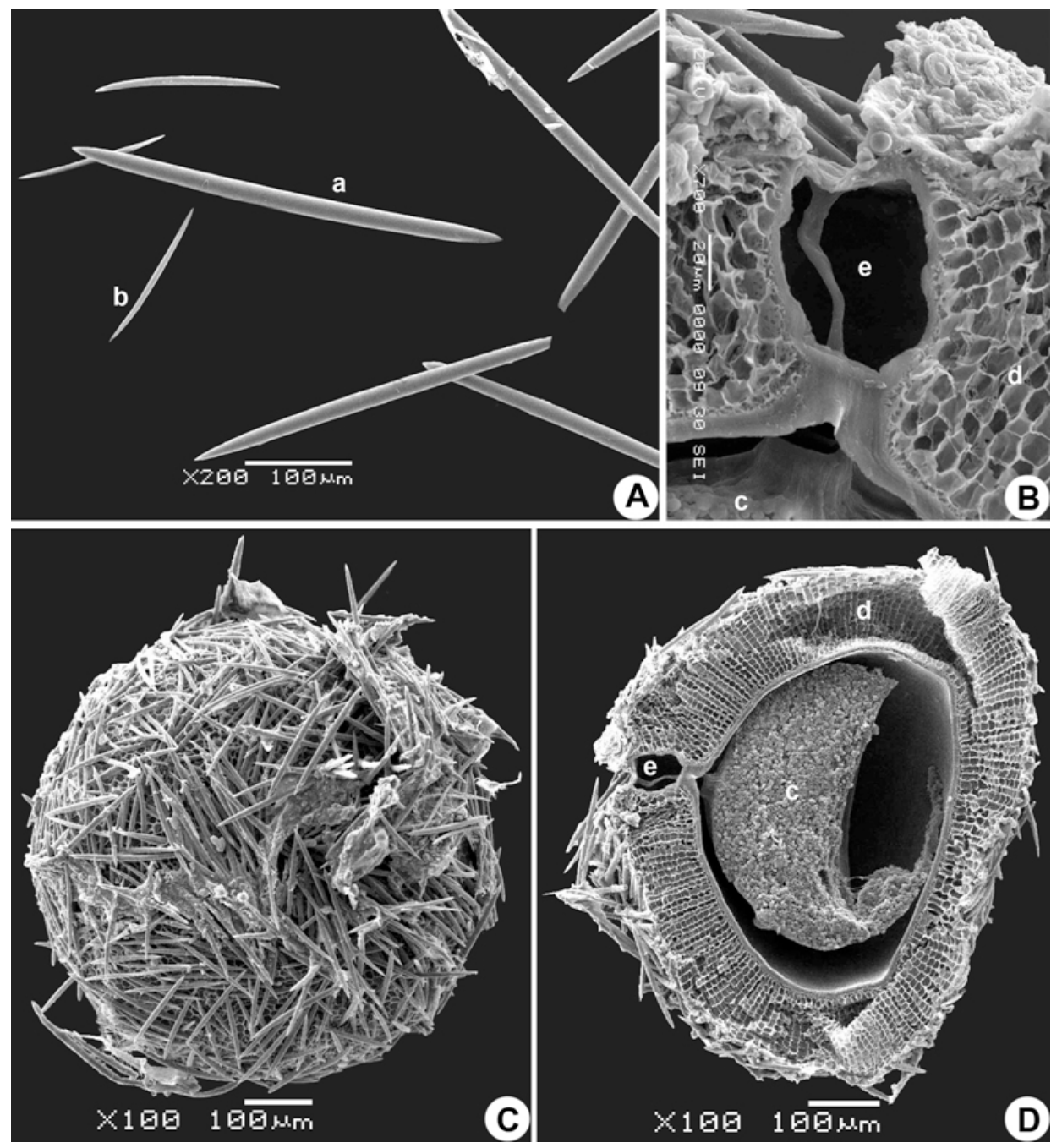

Image 13. Eunapius carteri spicules and gemmules. A - megascleres and gemmuloscleres; B - pneumatic layer \& foraminal tube;

C - gemmule; D - cross-section of gemmule; a - megasclere, smooth and stout oxeas; b - gemmulosclere, smooth and slender oxeas; c - mass of thesocytes; $d$ - thick, cellular pneumatic layer; e - foramen \& foraminal tube.

C. bhavnagarensis is a relatively recent addition to the Indian freshwater sponge fauna (Soota et al. 1983; Soota 1991). This species however has apparently been not taken into the account while compiling all freshwater sponges under a single suborder: Spongillina by Manconi \& Pronzato (2002). Ruengsawang et al. (2012) have listed C. bhavnagarensis under the Genus Corvospongilla and World Porifera Database also maintains it as a valid species. C. bhavnagarensis and C. lapidosa are endemic to Indian region (Annandale 1911; Penney \& Racek 1968; Soota et al. 1983; Soota 1991; Manconi \& Pronzato 2002).

Corvospongilla lapidosa were found in the same Tank at Pashan, Pune in February 2012 (collector S.S. Jakhalekar) (Images 2\&3).

Habitus (Image 14): Enormously spread encrustations of Corvospongilla lapidosa were found on vertical surface of the rocky wall of Pashan Tank (Image 3). Maximum length of the encrusted growth recorded is nearly $0.75 \mathrm{~m}$; though, thickness was never greater than $1-1.5 \mathrm{~cm}$. Sponge has peculiar morphology with colour ranging from off-white, grey to black, perhaps due to trapped silt (Image 14). The surface is corrugated and studded with vertical spiny spicular projections, thus called 'hispid' (Boury-Esnault \& Ruetzler 1997). Oscula are small, not more than $1 \mathrm{~mm}$ in diameter, thus inconspicuous. Consistency is hard due to thick skeletal meshwork formed by large number of spicules.

\section{Diagnostic characters}

Spicules (Image 15A-C): Megascleres are stout, nearly straight or feebly curved, entirely smooth strongyles 
(189-250 x 18-21 $\mu \mathrm{m})$ (Image 15A). Microscleres, scarcely present, are micro-birotulates with slender, smooth shaft ending in 6-8 recurved spines giving it an appearance similar to the umbonate, deeply notched rotule $(18-36 \times 2-4 \mu \mathrm{m}$; diameter of rotules: 7-13 $\mu \mathrm{m}$ ) (Image 15C). Gemmuloscleres are stout, straight or slightly curved strongyles, covered with blunt microspines, some of which are slightly back-curved, spine at the tip is broad and straight $(21-39 \times 5-9 \mu \mathrm{m})$ (Image 15B).

Gemmules (Image 15D\&E): Gemmule number was extremely large and all gemmules were concentrated at the base of the sponge. Region towards surface showed no gemmules. Gemmules are about spherical or subspherical in shape (diameter: 725-1000 $\mu \mathrm{m}$ ) (Images $15 D \& E)$. The pneumatic layer is poorly developed having irregular consistency and very small air-spaces (Image 15E). Annandale (1911) and Penney \& Racek (1968) describe the gemmuloscleres to be attached to the outside of gemmule in mosaic pattern. We, however, could not observe such pattern of arrangement in our specimen. Foramen was just raised above the surface.

\section{Discussion}

These five species of freshwater sponges are known from India (Annandale 1911; Penney \& Racek 1968; Soota 1991) and Maharashtra as well (Patil \& Talmale 2007). Tonapi (1964), however, had missed D. plumosa and $R$. cerebellata in his short-note on freshwater sponges of Pune. This paper makes an addition of these two species to the checklist of freshwater sponges of Pune City. Besides, this is probably the first photographic documentation of spicules under SEM as well as photos

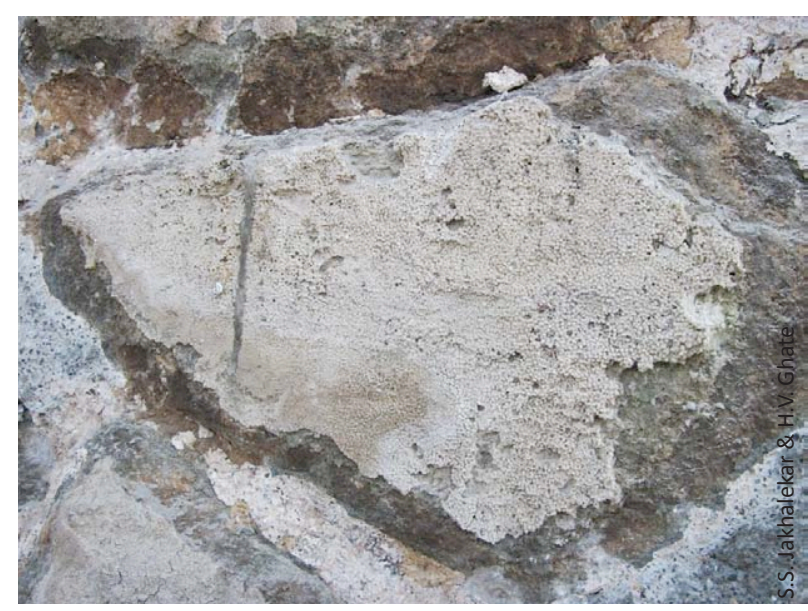

Image 14. Corvospongilla lapidosa habitus, off-white to grey stony hard encrustations. of habitus of each sponge reported here, as we are not aware of any similar publication by earlier Indian workers.

The structure of spicules (from body as well as from gemmules) conforms to that described by earlier workers like Annandale (1911) and Penney \& Racek (1968). Measurement of spicules shows that these spicules are within the size-range published earlier (Penney \& Racek 1968). Gemmule structure, especially seen in cross section with SEM, has not been mentioned by earlier Indian researchers though Manconi \& Pronzato (2002) have studied some of these sponges with SEM. In a detailed paper on gemmule structure, and the role of gemmules in dispersal and natural history of freshwater sponges, Manconi \& Pronzato (2007) have emphasized that cryptobiosis associated with gemmules has played a significant role as an efficient device for survival under dry conditions and subsequent dispersal. These authors have also discussed the role of pneumatic layer and spicule-layers in the wall or theca of the gemmules and other aspects of gemmule structure; these layers have been shown in our species and their structure matches with the description given by Manconi \& Pronzato (2007). We have observed that there are literally thousands of gemmules with even a moderate sized (diameter about $15 \mathrm{~cm}$ ) Ephydatia meyeni and we can imagine how many potential new sponges can arise from these gemmules, as these spread away from dry sponge. Certainly this capacity to produce vast number of gemmules which can resist dry period must have helped freshwater sponges to survive and disperse in a vast number of suitable habitats all over the world.

We now feel that modern techniques like SEM imaging or DNA based phylogeny must be employed to solve the intricacies of taxonomy/phylogeny of freshwater sponge in India. Fresh collection revealing new localities and careful biological observations are very much needed for the establishment of sound taxonomic base for freshwater sponges in India. This is necessary because Manconi \& Pronzato (2007) are of the opinion that the present number of species of freshwater sponges is an underestimation and that additional detailed work is likely to reveal more species. More detailed work is therefore likely to reveal additional species of freshwater sponges.

\section{REFERENCES}

Annandale, N. (1907). Description of two new Freshwater Sponges from Eastern Bengal, with remarks on allied forms. Records of Indian Museum 1: 387-392. 


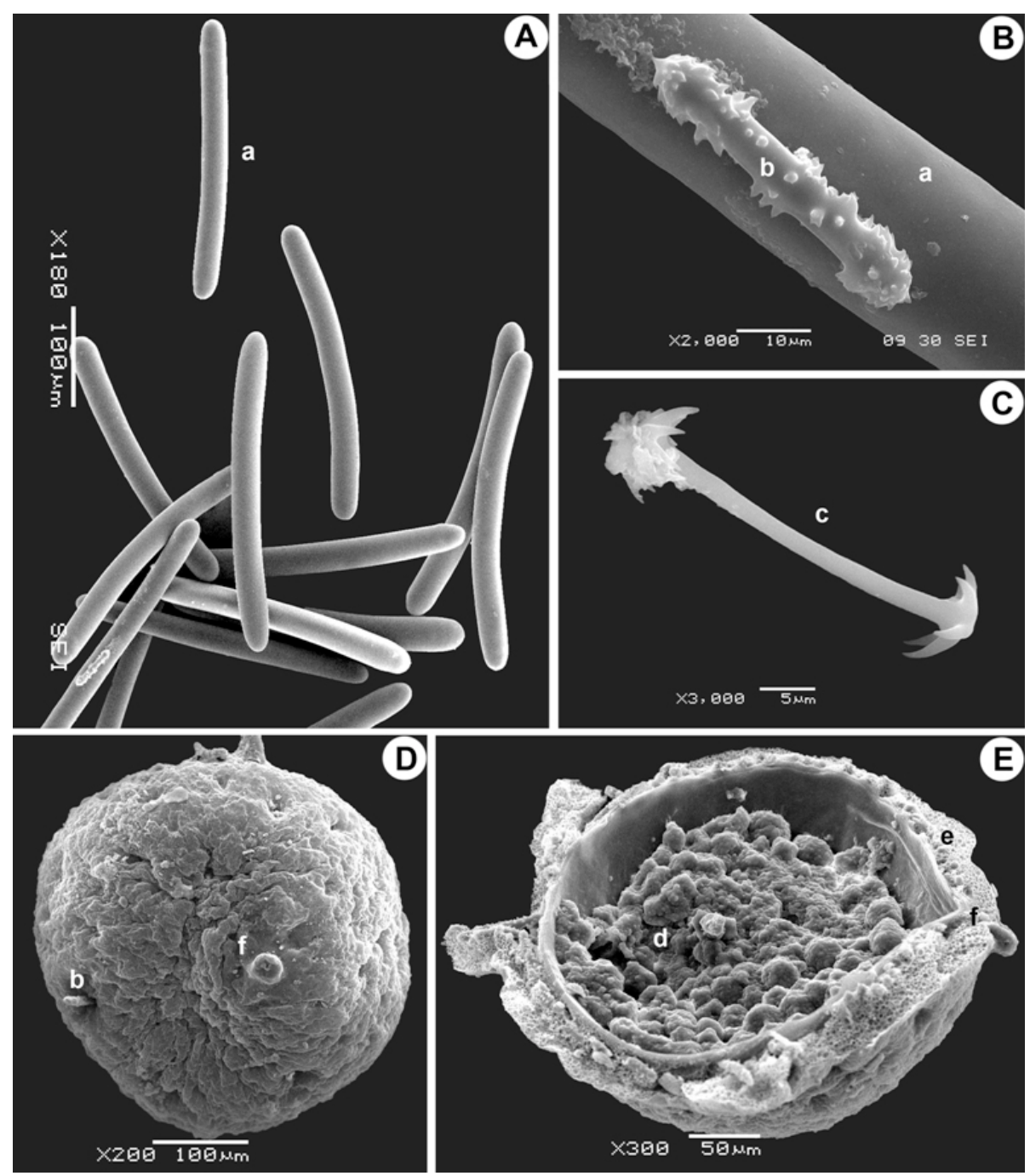

Image 15. Corvospongilla lapidosa spicules and gemmules. A-C - megascleres, gemmulosclere and microsclere; D - gemmule; E - crosssection of gemmule; a - megasclere, smooth stongyles; b-gemmulosclere, micro-spined strongyles; c - microscleres, micro-birotulates with smooth shaft and recurved hooks at the tips; $d$ - mass of thesocytes; $e$ - poorly developed pneumatic layer; $f$ - foramen.

Annandale, N. (1911). The Fauna of British India, including Ceylon and Burma. Freshwater Sponges, Hydroids and Polyzoa. Taylor and Francis, London, 251pp.

Boury-Esnault N. \& K. Ruetzler (1997). Thesaurus of Sponge Morphology. Smithsonian Contributions to Zoology (No. 596), $55 \mathrm{pp}$.

Cândido, J.L., C. Volkmer-Ribeiro \& K. Fürstenau-Oliveira (2010). Dosilia (Porifera, Demospongiae) redefined. Iheringia, Série Zoologia 100(4): 425-448

Devarshi, D. (2006). Record of freshwater sponge Eunapius carter (Bowerbank, 1863) from Keladevi Wildlife Sanctuary, Rajasthan Zoos' Print Journal 21(6): 2284; http://dx.doi.org/10.11609/JoTT. ZPJ.1442.2284

Dutta, S.P.S., V. Kumari \& S. Kumar (2000). An ecological study of sponges in a freshwater pond in Jammu, Jammu and Kashmir State, India. Journal of Aquatic Biology 15(1\&2): 23-25.

Kakavipure, D.K. \& S.G. Yeragi (2008). Occurrence of fresh water sponge Eunapius carteri (Bowerbank, 1863) from Khativali-Vehloli Lake near Shahapur District, Thane, Maharashtra, India, pp. 500505. In: Sengupta, M. \& R. Dalwani (eds.). Proceedings of Taal 2007 The $12^{\text {th }}$ World Lake Conference.
Khera, S. \& Y. Chaturvedi (1976). Checklist of Indian freshwater sponges, with a catalogue of type - specimens in the collection of the Zoological Survey of India (Porifera: Spongillidae). Records of Zoological Survey of India, Miscellaneous Publication, Occasional Paper No. 4: 1-29.

Manconi, R. \& R. Pronzato (2002). Suborder Spongillina subord. nov.: Freshwater sponges, pp. 921-1019. In: Hooper, J.N.A. \& R.W.M. van Soest (eds.). Systema Porifera: A Guide to the Classification of Sponges-Vol. 1. Kluwer Academic/Plenum Publishers, New York.

Manconi, R. \& R. Pronzato (2004). The genus Corvospongilla Annandale (Haplosclerida, Spongillina, Spongillidae) with description of a new species from eastern Mesopotamia, Iraq. Archiv fur Hydrobiologie. Supplement volumes, Monographic studies, 151: 161-189.

Manconi, R. \& R. Pronzato (2007). Gemmules as a key structure for the adaptive radiation of freshwater sponges: a morphofunctional and biogeographical study, pp. 61-77. In: Custódio, M.R., G. LôboHajdu, E. Hajdu \& G. Muricy (eds.). Porifera Research: Biodiversity, Innovation and Sustainability. Série Livros 28. Rio de Janeiro: Museu Nacional.

Manconi, R. \& R. Pronzato (2008). Global biodiversity of sponges (Porifera: Spongillina) in freshwater. Hydrobiologia 595: 27-33. 
Nation, J.L. (1983). A new method using hexamethyldisilazane for preparation of soft insect tissues for Scanning Electron Microscopy. Stain Technology 58(6): 347-351.

Osborn, A.W., G. Nigel, R. Forteath \& J. Stanisic (2008). A new species of freshwater sponge (Porifera: Spongillidae) of the genus Radiospongilla from Lake Pedder in Tasmania. Papers and Proceedings of the Royal Society of Tasmania 142(2): 39-44.

Patil, S.G. (1986). New records of sponges (Porifera) from Andhra Pradesh, with a note on its ecology. Geobios 5: 167.

Patil, S.G. \& S.S. Talmale (2007). Checklist of freshwater sponges (Porifera) of Maharashtra. Bionotes 9(2): 52-53.

Penney, J.T. \& A.A. Racek (1968). Comprehensive revision of a worldwide collection of freshwater sponges (Porifera: Spongillidae). Bulletin of U.S. National Museum, No. 272, 184pp.

Rao, I.S. \& M.A. Khan (1982). Ecobiology of Corvospongilla lapidosa (Annandale, 1908) (Porifera: Spongillidae) in the Manjira reservoir, Sangareddy, Andhra Pradesh. Proceedings of Indian Academy of Science (Animal Science) 91(6): 553-562.

Ruengsawang, N., N. Sangpradub, C. Hanjavanit \& R. Manconi (2012) Biodiversity assessment of the Lower Mekong Basin: a new species of Corvospongilla (Porifera: Spongillina: Spongillidae) from Thailand. Zootaxa 3320: 47-55.
Soota, T.D. (1991). Freshwater Sponges of India. Occasional Paper No. 138. Records of the Zoological Survey of India. Zoological Survey of India, Culcutta, 116pp.

Soota, T.D. \& J.G. Pattanayak (1982). On some freshwater sponges from the unnamed collection of the Zoological Survey of India. Records of Zoological Survey of India 80: 215-229.

Soota, T.D., J.G. Pattanayak \& M.M. Saxena (1983). On some freshwater sponges from Gujarat (India). Records of Zoological Survey of India 81: 255-260.

Tonapi, G.T. (1964). A note on the freshwater sponges of Poona. Current Science 12: 372-373.

van Soest, R.W.M., N. Boury-Esnault, J. Vacelet, M. Dohrmann, D. Erpenbeck, N.J. De Voogd, N. Santodomingo, B. Vanhoorne, M. Kelly \& J.N.A. Hooper (2012). Global Diversity of Sponges (Porifera). PLOS ONE 7(4): e35105; http://dx.doi.org/10.1371/journal. pone.0035105

van Soest, R.W.M., N. Boury-Esnault, J.N.A. Hooper, K. Rützler, N.J. de Voogd, B. Alvarez de Glasby, E. Hajdu, A.B. Pisera, R. Manconi, C. Schoenberg, D. Janussen, K.R. Tabachnick, M. Klautau, B. Picton, M. Kelly, J. Vacelet, M. Dohrmann \& M. Cristina Díaz (2013). World Porifera database. Accessed at http://www.marinespecies.org/ porifera on 19 May 2013. 